\title{
Correction to: Musculoskeletal disorders and their associations with health- and work-related factors: a cross-sectional comparison between Swedish air force personnel and army soldiers
}

Matthias Tegern ${ }^{1,2^{*}}$, Ulrika Aasa ${ }^{1}$, Björn O. Äng ${ }^{2,3,4}$ and Helena Larsson ${ }^{2,5}$

\section{Correction to: BMC Musculoskelet Disord 21, 303 (2020) https://doi.org/10.1186/s12891-020-03251-z}

Following publication of the original article [1], the authors noticed that the numbers $1-5$ in the Methods section under subsection "Health- and work-related questions" were mistakenly interpreted as references.

Health- and work-related questions

"To assess their self-rated general health, the following questions were used: How do you experience your [1] "physical health" [2] "mental health" [3] "social environment" [4] "physical environment" and [5] "work ability"? A seven-point scale with answers ranging from "very poor" to "excellent, cannot be better" was used. In the analyses, the answers were collapsed and coded into: poor $(\leq 3)$, good $[4,5]$, or excellent $(\geq 6)$ according to Larsson et al. [16]."

The original article [1] has been updated.

\section{Author details}

'Department of Community Medicine and Rehabilitation, Unit of

Physiotherapy, Umeå University, Umeå, Sweden. ${ }^{2}$ Department of Neurobiology, Care Sciences and Society, Division of Physiotherapy,

Karolinska Institutet, Huddinge, Sweden. ${ }^{3}$ School of Education, Health and
Social Studies, Dalarna University, Falun, Sweden. ${ }^{4}$ Centre for Clinical Research Dalarna, Uppsala University, Falun, Sweden. ${ }^{5}$ Swedish Armed Forces, HQ, Stockholm, Sweden.

Published online: 10 October 2020

\section{Reference}

1. Tegern M, Aasa U, Äng BO, et al. Musculoskeletal disorders and their associations with health- and work-related factors: a cross-sectional comparison between Swedish air force personnel and army soldiers. BMC Musculoskelet Disord. 2020;21:303. https://doi.org/10.1186/s12891-02003251-z.

The original article can be found online at https://doi.org/10.1186/s12891020-03251-z

*Correspondence: matthias.tegern@umu.se

'Department of Community Medicine and Rehabilitation, Unit of Physiotherapy, Umeå University, Umeå, Sweden

2Department of Neurobiology, Care Sciences and Society, Division of

Physiotherapy, Karolinska Institutet, Huddinge, Sweden

Full list of author information is available at the end of the article

C The Author(s). 2020 Open Access This article is licensed under a Creative Commons Attribution 4.0 International License, which permits use, sharing, adaptation, distribution and reproduction in any medium or format, as long as you give appropriate credit to the original author(s) and the source, provide a link to the Creative Commons licence, and indicate if changes were made. The images or other third party material in this article are included in the article's Creative Commons licence, unless indicated otherwise in a credit line to the material. If material is not included in the article's Creative Commons licence and your intended use is not permitted by statutory regulation or exceeds the permitted use, you will need to obtain permission directly from the copyright holder. To view a copy of this licence, visit http://creativecommons.org/licenses/by/4.0/. The Creative Commons Public Domain Dedication waiver (http://creativecommons.org/publicdomain/zero/1.0/) applies to the data made available in this article, unless otherwise stated in a credit line to the data. 